\title{
ROLA SZKOŁY W PROCESIE KONSTRUOWANIA PRZEZ DZIECKO ROLI CZWARTOKLASISTY
}

\begin{abstract}
Streszczenie: Proces wchodzenia ucznia w rolę czwartoklasisty wiąże się z koniecznością opanowania nowego repertuaru zachowań, które stanowią odpowiedź na zmiany zachodzące w przestrzeni codzienności szkolnej. Dobrze opanowany system zachowań trzecioklasisty nie sprawdza się w rzeczywistości edukacji przedmiotowej. To pociąga za sobą konieczność zmian na poziomie intrapsychicznym i interpsychicznym. Adaptacja zatem przez wchodzenie w rolę może stać się formą rozwoju ucznia, zwłaszcza wtedy, gdy opiera się na inicjowaniu zmian rozwojowych. Jednocześnie jednak niesie także ryzyko niekorzystnych zmian, gdy uczeń doświadcza jedynie silnej presji zewnętrznej, a przy tym nie dysponuje odpowiednimi zasobami, doświadcza deprywacji ważnych dla niego potrzeb i nie może liczyć na adekwatne wsparcie społeczne. Wówczas adaptacja do roli może przybierać nawet formy patologiczne. W tekście tym podjęto rozważania dotyczące istoty i znaczenia wsparcia społecznego udzielanego przez szkołę uczniom podejmującym rolę czwartoklasisty, skupiając się głównie na zadaniach nauczycieli.
\end{abstract}

Słowa kluczowe: konstruowanie roli czwartoklasisty, strategie adaptacyjne, wsparcie adaptacyjne, zadania nauczycieli, edukacja przedmiotowa

\section{WPROWADZENIE}

Człowiek stopniowo, w trakcie osobniczego rozwoju, dzięki relacjom ze światem zewnętrznym i w zasadzie ogromnym możliwościom poznawczym, uczy się określonego repertuaru technik adaptacyjnych, form zachowania, kształtuje nawyki, umiejętności, zbiera doświadczenia i czynnie kreuje swoją tożsamość. Każdy człowiek w biegu swego życia zdobywa doświadczenia stanowiące rezultat jego aktywności w świecie. Suma tych doświadczeń buduje jego indywidualne, jednostkowe doświadczenie życiowe. Doświadczenie to ulega nieustannym prze- 
mianom, modyfikując pozycję jednostki w świecie, przekształcając jej stosunek do świata zewnętrznego i wewnętrznego, co z kolei prowadzi do ponownej jego reorganizacji i restrukturyzacji, a w konsekwencji rozwoju. Proces ten trwa całe życie, choć jego dynamika jest różna na poszczególnych jego etapach.

Doświadczenie życiowe ma wymiar osobisty, indywidualny, gdyż jest niepowtarzalne $\mathrm{w}$ swej treści, formach i dynamice. W niektórych jednak aspektach posiada wymiar uniwersalny, który wynika $\mathrm{z}$ faktu jednolitego, charakterystycznego dla rozwoju ludzkiego następstwa określonych jego faz i zadań życiowych, jakie im odpowiadają.

Do takich wydarzeń można zaliczyć przekraczanie progu edukacji przedmiotowej i tym samym podjęcie społecznej roli czwartoklasisty. Stopniowe opanowywanie repertuaru zachować charakterystycznych dla pełnionej roli wiąże się z koniecznością konfrontacji ze zmianami, które plasują się głównie w płaszczyźnie aktywności zadaniowej ucznia, społecznej i organizacyjnej. Zmiany te powodują określone konsekwencje. Mogą zakłócać, modyfikować, czasem nawet blokować dalsze działanie ucznia, a w konsekwencji jego rozwój. Z drugiej jednak strony mogą uruchomić, zainicjować sekwencję przemian wewnętrznej struktury obiektu, a więc doprowadzić do jakościowych przeobrażeń jej elementów, niektórych relacji między nimi czy też całego układu powiązań. Wówczas uczeń może stopniowo pokonywać kolejne wyzwania i tym samym osiągać coraz wyższe etapy rozwoju, szczególnie w sytuacji, gdy rzeczywiście posiada odpowiednie zasoby (np. silną motywację, predyspozycje, zalążki określonych umiejętności itp.), a przede wszystkim, gdy otrzyma w odpowiednim czasie adekwatne wsparcie. W tekście tym podjęto rozważania dotyczące istoty i znaczenia wsparcia społecznego udzielanego przez szkołę uczniom podejmującym rolę czwartoklasisty.

\section{ZMIANA JAKO ŹRÓDŁO ROZWOJU UCZNIA}

Proces wchodzenia ucznia w rolę czwartoklasisty wiąże się z koniecznością opanowania nowego repertuaru zachowań, które stanowią odpowiedź na zmiany zachodzące w przestrzeni codzienności szkolnej. Przyjmują one postać wyzwań natury społecznej, zadaniowej i organizacyjnej.

Wchodzenie w rolę czwartoklasisty wymaga konstruowania odmiennych relacji społecznych z nauczycielami i rówieśnikami oraz starszymi i młodszymi kolegami. Zmianom podlegają także stosunki społeczne w środowisku rodzinnym. Wskaźnikiem właściwie przebiegającej adaptacji społecznej jest dążenie do nawiązywania i podtrzymywania pozytywnych kontaktów społecznych, umie- 
jętność współpracy i poczucie przynależności do społeczności szkolnej (Hajnicz, Konieczna 2013; Wilski 2013).

Zmiany w sferze zadaniowej wynikają głównie z wymagań stawianych przez nauczycieli oraz wynikających z programu nauczania. Wiążą się z oczekiwaniami dotyczącymi zdecydowanie większej samodzielności i niezależności od osób dorosłych (Wilski 2013). Powstające trudności adaptacyjne w tym obszarze funkcjonowania ucznia wynikają z niewłaściwego dopasowania wymagań do jego możliwości i oczekiwań. Konsekwencją tego stanu rzeczy jest zbieranie negatywnych informacji o samym sobie, co sprzyja budowaniu negatywnej samooceny oraz prowadzi do zahamowania aktywności zadaniowej ucznia (Hajnicz, Konieczna 2013).

Zmiany organizacyjne wynikają zaś z hierarchicznego uporządkowania środowiska szkolnego. Szkoła, będąc jednostką organizacyjną, wyznacza ramy działania, w których podmioty edukacyjne przestrzegają określonych, standardowych wzorców zachowań. Przyswojenie tych form postępowania to niezwykle ważne zadanie stawiane przed uczniem.

Zarysowane powyżej kategorie zmian przestrzeni aktywności edukacyjnej ucznia można zoperacjonalizować i w związku z tym wyróżnić następujące elementy strukturalne:

- większa liczba nauczycieli o zróżnicowanych wymaganiach, stylu komunikowania, formach i metodach pracy, strategiach funkcjonowania, filozofiach kształcenia;

- nowe przedmioty nauczania wymagające więcej nauki, specyficznego języka, kodowania i dekodowania znaczeń, zwykle o wyższym stopniu trudności i złożoności zadań, wymagające zróżnicowanych stylów myślenia i uczenia się;

- większa ilość zadań domowych (a więc mniej czasu na zabawę) wymagających umiejętności efektywnego gospodarowania czasem i wysiłkiem;

- nowy cyfrowy system oceniania, wymagający odmiennych form zachowania receptywnego i reaktywnego;

- oczekiwania większej odpowiedzialności za siebie i swoje postępowanie, większej samodzielności w zakresie psychospołecznego i fizycznego funkcjonowania;

- wymagana większa sprawność poznawcza - szybsze tempo pisania, czytania, liczenia, zapamiętywania, wypowiadania się;

- wymagana większa dyscyplina i konieczność respektowania w większym zakresie norm szkolnych i grupowych;

- nowe sposoby kontrolowania, sprawdzania postępów ucznia, wymagające większej autokontroli poznawczej i emocjonalnej;

- $\quad$ wchodzenie w nowe role społeczne przez większy udział w życiu szkoły; 
- odmienny rytm życia szkolnego wyznaczany dzwonkami;

- spędzanie przerw z większą społecznością szkolną;

- przemieszczanie się po szkole - większa swoboda, konieczność przechodzenia $\mathrm{z}$ jednej sali do drugiej.

Każda zmiana ma zarówno charakter obiektywny, jak i subiektywny i cechuje się specyficznymi właściwościami. Po pierwsze, zmiana zawiera w sobie zarówno zagrożenie, jak i szansę dla rozwoju ucznia. Oznacza to, że z jednej strony w szczególnie niesprzyjających warunkach (zbyt wygórowane oczekiwania społeczne w stosunku do wewnętrznych zasobów ucznia) może dojść do poważnej dekompensacji, a więc załamania mechanizmów obronnych, wycofywania się, fobii, epizodycznego zaburzenia poznawczego, społecznego, niekorzystnych objawów psychosomatycznych. To może upośledzać czasowo, a nawet chronicznie funkcjonowanie dziecka w podstawowych rolach i relacjach społecznych i tym samym blokować możliwości rozwoju. Z drugiej strony zmiana może stanowić szansę, gdy mobilizuje jednostkę do podjęcia działań, nowych form aktywności psychicznej i fizycznej, które stają się źródłem doświadczeń ważnych w procesie „obłaskawiania” zmiany. Jednocześnie wobec doświadczanego lęku zrodzonego z poczucia utraty równowagi, wewnętrznej homeostazy jednostka może sięgać po niestandardowe rozwiązania, uruchamiać własne zasoby, mobilizować organizm do wysiłku i otworzyć się na system wsparcia zewnętrznego, który staje się drogą do rozwiązania problemów i tym samym pokonania aktualnych możliwości rozwoju. Zwrócenie się ku osobom kompetentnym, oddanie się działaniom twórczym, innowacyjnym to otwarcie na strefę najbliższego rozwoju.

Charakterystyczną cechą zmiany jest także jej jednoczesna uniwersalność i niepowtarzalność, wyjątkowość. Uniwersalność zmiany wyraża się w jej powszechności, gdyż każdy uczeń w przebiegu kariery szkolnej jej doświadcza. Uniwersalność zmiany wiąże się także z konsekwencjami, jakie wywołuje w jednostce. Powszechnymi efektami doświadczania zmiany jest czasowe zachwianie równowagi, dezorganizacja, a także silne przeżycia emocjonalne, jak lęk, obniżony nastrój, niepokój czy poczucie utraty autokontroli. Wyjątkowość zmiany zawiera się w jej indywidualnym, subiektywnym odbiorze i konsekwencjach, jakie może przynieść dla indywidualnego rozwoju ucznia. Te same zdarzenia mogą mieć odmienny wpływ na różne osoby. To, co dla jednych stanowi sytuację trudną o umiarkowanym nasileniu, problem niełatwy, lecz możliwy i rozwiązywalny, dla kogoś innego może być przyczyną „utraty gruntu pod nogami”, absolutną katastrofą, nawet jeśli zmianie towarzyszą podobne obiektywne okoliczności. Trudno także przewidzieć, czego będą dotyczyły zmiany, jakie nastąpią w rozwoju ucznia. Zależą one od różnych subiektywnych czynników (zasoby psychofizyczne jednostki, wrażliwość, odporność na stymulację, poziom rozwoju itp.), a także adekwatne- 
go wsparcia społecznego. Z jednej strony mogą doprowadzić do rozwoju wzwyż przez dostarczanie doświadczeń reorganizujących dotychczasowe struktury na poziomie psychicznym i behawioralnym, powodując większą skuteczność ucznia i poczucie zadowolenia, $z$ drugiej zaś strony mogą spowodować zastój, a nawet regres w rozwoju. Poza tym zmiana może doprowadzić do rozwoju na różnych poziomach i obszarach: $w$ relacjach do siebie, świata globalnego lub lokalnego, w systemie zachowań, osobowości lub procesach psychicznych.

Zmianę charakteryzuje także wielowymiarowość i złożoność pojęciowa. Trudno je opisać przez wyliczenie jasno zdefiniowanych cech. Jednocześnie niełatwo ująć je w kategoriach przyczynowo-skutkowych. Ich obraz jest złożony, gdyż determinują je zarówno czynniki natury intrapsychicznej i interpsychicznej, a także relacyjnej. Zmiana zazwyczaj dotyka wszystkich obszarów funkcjonowania ucznia, a odpowiedź na nią i pomoc dziecku w tym zadaniu wymaga zwykle interwencji wieloaspektowej, uwzględniającej wszystkie ważne konteksty jego rozwoju (rodzina, szkoła, grupa rówieśnicza).

Zmiana, $z$ uwagi na złożony obraz kliniczny, wymaga także niestandardowych rozwiązań, najczęściej rozłożonych w czasie. Właściwie nie istnieją uniwersalne i szybkie strategie jej pokonywania. Można jedynie mówić o pewnych ogólnych dyrektywach interwencji stanowiących swoisty rodzaj ramy, którą należy wypełnić indywidualną treścią, adekwatną dla danej osoby (jej płci, indywidualnych zasobów, potrzeb...) i konkretnej sytuacji oraz okoliczności zmiany.

Doświadczanie zmiany popycha ucznia do wyboru określonej strategii działania. Oczywiście może podejmować aktywność w sposób mniej lub bardziej świadomy. Ignorowanie jednak zmiany, czyli niechęć do wysiłku odpowiedzi na nią, powoduje zwykle negatywne konsekwencje dla rozwoju ucznia, a w niektórych przypadkach może prowadzić do destrukcji. Podjęcie działania, nawet początkowo nieadekwatnego do istoty zmiany, jest mobilizacją organizmu i pierwszym krokiem do zmiany biegu zdarzeń i toru biografii psychicznej (Michalak 2013).

Scharakteryzowane powyżej zmiany stają się atrybutami edukacji przedmiotowej w odniesieniu do specyfiki dotychczasowego sposobu organizowania warunków edukacyjnego rozwoju ucznia, zwłaszcza na etapie edukacji zintegrowanej. Stają się jednak rzeczywistością, która wymaga od ucznia zmian adaptacyjnych. Dotychczasowe bowiem zachowania stają się nieadekwatne, nieskuteczne, a próby ich bezwzględnego aplikowania niosą niekorzystne zmiany psychiczne. Dobrze opanowany system zachowań trzecioklasisty nie sprawdza się w rzeczywistości edukacji przedmiotowej. Uczeń doświadcza dysonansu, zostaje zachwiana jego równowaga psychiczna. Dotychczasowe formy funkcjonowania nie sprawdzają się także w konfrontacji z nowym przepisem roli. To pociąga za sobą konieczność zmian na poziomie intrapsychicznym i interpsychicznym. Zmiany te wymagają 
zatem od ucznia readaptacji szkolnej. Readaptacja jest jednak możliwa jedynie przez aktywne uczestnictwo ucznia. Musi się on zmagać ze zmianami, podejmując zróżnicowane formy aktywności, które dostarczać będą konstruktywnych doświadczeń. Te, w konfrontacji z dotychczasowymi, zapoczątkowują proces transformacji struktury doświadczeń i z reguły przynoszą nowe osiągnięcia rozwojowe.

W procesie konstruowania roli ucznia klasy czwartej można wyróżnić pewne, jakościowo odmienne etapy: (1) wchodzenie w rolę, które polega najpierw na zdobywaniu podstawowych informacji na temat przepisu roli i warunków, a więc sposobu jej realizacji zdefiniowanego przez system oczekiwań społecznych. Następnie uczenie się zachowań zgodnych z przepisem roli, głównie przez naśladowanie postępowania innych; (2) pełna adaptacja do roli, którą cechuje coraz sprawniejsze i bardziej efektywne realizowanie przepisu roli, dzięki adekwatnemu posługiwaniu się wiedzą i umiejętnościami, oraz wprowadzanie zmian do przepisu roli, jednak tylko w ramach rozpoznanej konwencji; modyfikacje nie dotyczą celów działań; (3) twórcze przekraczanie roli, które wyraża się w kreatywnym zindywidualizowanym posługiwaniu się już posiadaną wiedzą, umiejętnościami i doświadczeniami oraz przekraczanie przepisu roli zgodnie z własnymi celami i wizją osobistego rozwoju (Brzezińska 2004; Michalak 2013).

Adaptacja zatem przez wchodzenie w rolę może stać się formą rozwoju ucznia, zwłaszcza wtedy, gdy opiera się na inicjowaniu zmian rozwojowych. Jednocześnie jednak niesie także ryzyko niekorzystnych zmian, gdy uczeń doświadcza jedynie silnej presji zewnętrznej, a przy tym nie dysponuje odpowiednimi zasobami, doświadcza deprywacji ważnych dla niego potrzeb i nie może liczyć na adekwatne wsparcie społeczne. Wówczas adaptacja do roli może przybierać nawet formy patologiczne.

\section{UWARUNKOWANIA ADAPTACJI UCZNIA DO ROLI CZWARTOKLASISTY}

Proces konstruowania roli ucznia czwartej klasy nie może odbywać się w warunkach sztucznych, wyizolowanych z codzienności edukacyjnej ucznia. Właściwy, konstruktywny proces adaptacji do roli dokonuje się w naturalnych sytuacjach życia szkolnego oraz przez życie szkolne i jest niejako produktem ubocznym aktywności ucznia, a nie celem samym w sobie.

Proces konstruowania roli czwartoklasisty z perspektywy ucznia to zdobywanie, gromadzenie i przetwarzanie różnorodnych, bogatych w formę i treść doświadczeń. Doświadczenia te stanowią fundament zmian psychofizycznych, które czynią ucznia gotowym do pokonywania kolejnych wyzwań wynikających $\mathrm{z}$ repertuaru roli. $\mathrm{Z}$ perspektywy nauczyciela zaś to organizowanie ciągu 
przemyślanych sytuacji edukacyjnych, dostosowanych do potrzeb i możliwości dziecka, tworzących logiczną strukturę podporządkowaną jakości rozwojowych doświadczeń. Mówiąc językiem Rudolfa Schaffera, to ciąg epizodów wzajemnego zaangażowania ucznia i nauczyciela, w których ich aktywność wzajemnie się przeplata, uzupełnia i wzbogaca. Od ich bogactwa i różnorodności zależy jakość i dynamika konstruowania roli czwartoklasisty.

Konstruowanie roli czwartoklasisty uwarunkowane jest współdziałaniem różnorodnych determinant tworzących skomplikowaną, często trudną do określenia sieć połączeń czynników genetycznych i środowiskowych. Na czynniki genetyczne szkoła nie ma wpływu, czynniki środowiskowe zaś współtworzy, a w niektórych zakresach jest ich wyłącznym kreatorem. Proces budowania roli ucznia edukacji przedmiotowej zależy m.in. od możliwości indywidualnych dziecka, wśród których najistotniejsze to zapewne: zdolności poznawcze, intelektualne, style myślenia, temperament, strategie uczenia się, tempo pracy, reaktywność na wzmocnienia, wrażliwość emocjonalna, stopień rozwoju układu nerwowego itp.

Zależy także od takich czynników, jak: rodzaj, treść i struktura zadania szkolnego, stopień atrakcyjności form i metod realizacji zajęć, styl komunikowania się z uczniami, system wsparcia psychicznego, fizycznego oraz system oceniania. $\mathrm{Na}$ ich ilość i jakość zdecydowanie największy wpływ wywiera sam nauczyciel.

Nie mniej ważne są także czynniki związane ze środowiskiem rodzinnym. Atmosfera domu rodzinnego, styl pełnienia funkcji rodzicielskich, poziom wykształcenia rodziców, ich aspiracje i oczekiwania, a także typ relacji, w jakie wchodzi dziecko z rodzicami i rodzeństwem różnicują możliwości adaptacyjne uczniów.

Proces konstruowania roli ucznia czwartej klasy determinowany jest w znacznej mierze, co już podkreślano, jakością relacji dziecka z nauczycielem i stylem jego ogólnego funkcjonowania. W związku z tym od nauczyciela oczekuje się ogólnych kompetencji świadczących o profesjonalizmie w zakresie osobowego, merytorycznego i metodycznego funkcjonowania. Jednocześnie oczekuje się pewnych specyficznych umiejętności, które warunkują dobre funkcjonowanie czwartoklasistów na starcie edukacji przedmiotowej. Chodzi zatem o te kompetencje, które wywierają wpływ na dobrą adaptację do roli ucznia i zapobiegają powstawaniu trudności w jej przebiegu, a także niwelują je, jeśli już wystąpiły. Oczekiwania dotyczą wszystkich nauczycieli uczących dzieci, ponieważ jakość ich pracy decyduje o funkcjonowaniu uczniów nie tylko na początku edukacji przedmiotowej. Specyfika nauczania przedmiotowego "rozmywa” niejako odpowiedzialność za jakość funkcjonowania czwartoklasistów, gdyż warunki dla ich edukacyjnego rozwoju kreuje wielu nauczycieli, a wychowawca pełni jedynie funkcję wspierającą.

Praca nauczycieli, zwłaszcza w pierwszych tygodniach nauki czwartoklasistów, powinna koncentrować się nie tylko na organizowaniu działań pomostowych, które 
pozwalają im dobrze adaptować się do życia szkolnego, ale także na wnikliwej obserwacji ich funkcjonowania, by jak najszybciej „wychwycić” tych, którzy przejawiają nawet niewielkie symptomy nieprzystosowania. Należy jednak podkreślić, że nauczyciele mogą efektywnie wpływać na przebieg procesu adaptacji ucznia do nowej roli czwartoklasisty dopiero po wstępnej jego aklimatyzacji i orientacji w nowych oczekiwaniach. Oczywiście nie powinni rezygnować także z działań profilaktycznych, a więc takich, które mogą podjąć jeszcze wtedy, kiedy uczeń funkcjonuje w przestrzeni edukacji elementarnej. Skuteczna pomoc uczniom $\mathrm{w}$ procesie konstruowania roli czwartoklasisty obejmuje w pierwszej kolejności diagnozę tych zasobów, które go ułatwiają i sprzyjają mu oraz tych, które go utrudniają. Zdobyte informacje są niezbędne nauczycielowi do uruchamiania określonych strategii pomocowych adekwatnych do potrzeb ucznia. Źródłem tej wiedzy nie powinni być tylko nauczyciele dotychczas uczący dzieci, gdyż często posługują się oni schematami, stereotypami i uprzedzeniami, ale sami uczniowie $i$ ich opiekunowie. Otwarta rozmowa oraz różne specjalnie zaaranżowane sytuacje pozwolą odkryć potencjał ucznia i ujawnić obszary szczególnie wrażliwe i podatne na zranienia.

Jednocześnie należy podkreślić, że wychowawca powinien jak najwcześniej podjąć odpowiednie działania także wobec rodziców i opiekunów zwłaszcza tych uczniów, u których pojawiają się pierwsze wskaźniki trudności adaptacyjnych. Zmiana sytuacji szkolnej dzieci związana z przekroczeniem progu edukacyjnego bardzo często wiąże się z większymi oczekiwaniami rodziców. Tymczasem zakłócenia w psychospołecznym funkcjonowaniu ich dzieci są dla nich niezrozumiałe i generują nieadekwatne reakcje. Rodzice zamiast zrozumienia często okazują rozczarowanie spowodowane brakiem postępów ich dzieci i nie potrafią odpowiednio pomóc, a nierzadko uciekają się do surowych kar. Dlatego już podczas pierwszego kontaktu $z$ rodzicami istotne jest, by nauczyciel poinformował ich o zmianach sytuacji edukacyjnej ich dzieci i zachęcił do wrażliwej obserwacji ich zachowania. Ponadto ważne, by przekazał informacje o tym, że każde dziecko we właściwy sobie sposób przeżywa trudności związane z odnalezieniem swego miejsca $\mathrm{w}$ nowej sytuacji i potrzebuje na to czasu oraz wsparcia, a przede wszystkim empatycznego zrozumienia, zaufania, bezwarunkowej akceptacji i afirmacji jego uczuć. Nauczyciel powinien także podpowiedzieć, jakie konkretne działania pomocowe może podjąć rodzic i do kogo zwrócić się po specjalistyczną pomoc, jeśli zwykłe czynności zawiodą. Stały kontakt, zwłaszcza z rodzicami dzieci przejawiających trudności adaptacyjne, należy do podstawowych zadań każdego nauczyciela. 


\section{ISTOTA WSPARCIA UCZNIÓW PRZEJAWIAJĄCYCH ZRÓŻNICOWANE STRATEGIE ADAPTACJI DO ROLI CZWARTOKLASISTY}

Proces wspierania uczniów w konstruktywnej adaptacji do nowej roli należy rozpatrywać, co już podkreślano, w szerokim kontekście uwarunkowań, wśród których niezwykle istotne są ich osobiste zasoby. To one głównie determinują jakość funkcjonowania dzieci w roli ucznia klasy czwartej i wyznaczają ich potrzeby w zakresie wsparcia. Dzieci wszelkimi dostępnymi sobie sposobami starają się odpowiedzieć na zmiany warunków życia szkolnego. Jeśli jednak zmiany znacznie przekraczają ich możliwości, a przy tym nie uzyskują one odpowiedniego wsparcia, proces kształtowania tożsamości czwartoklasisty może przybrać niekorzystny wymiar. W zachowaniu uczniów dość szybko daje się zauważyć różne symptomy tego zjawiska.

W procesie wspierania uczniów w pokonywaniu trudności w konstruowaniu roli czwartoklasisty ważne jest, by nauczyciel poszukiwał zarówno ich przyczyn, jak i sposobów przeciwdziałania im w złożonej dynamice powiązań czynników podmiotowych i sytuacyjnych. Takie spojrzenie pozwala mu dostrzec nowe możliwości wspomagania uczniów z trudnościami adaptacyjnymi i wczesnego zapobiegania rozwojowi patologii przez stosowanie szeroko rozumianych strategii równoważenia tych powiązań. Umożliwia mu także realną ocenę przebiegu procesu konstruowania społecznej roli ucznia przez czwartoklasistów oraz odmienną interwencję na różnych jej etapach.

Na poziomie oceny pierwotnej interwencja taka będzie głównie polegać na pomocy w reinterpretacji sytuacji i dostrzeżeniu jej dobrych stron. Na tym etapie ważne jest wytworzenie atmosfery wsparcia, bezpieczeństwa i akceptacji pomimo niepowodzeń. Takie poczucie umożliwi poznawczą przemianę znaczenia doświadczanych trudności z zagrożenia na wyzwanie, które można i należy podjąć. Na etapie oceny wtórnej pomoc powinna koncentrować się na rozwijaniu zasobów, zwiększaniu ich świadomości oraz umiejętności ich efektywnego wykorzystywania przy jednoczesnej regulacji poziomu obciążeń i ilości dostarczanego wsparcia. Takie podejście znacznie poszerza zakres możliwych do wykorzystania metod wspomagania adaptacji dziecka (Rychlewska 2006, s. 25).

Generalnie można mówić o dobrej i złej adaptacji do roli. Dobra, a więc aktywna, podmiotowa i konstruktywna, ma miejsce wtedy, gdy uczeń jest autonomiczny i spontaniczny we wszystkich obszarach szkolnego funkcjonowania. Dziecko dobrze wchodzące w rolę czwartoklasisty charakteryzuje naturalność, otwartość, aktywność, chęć podejmowania różnorodnych działań, domaganie się 
uwagi nauczyciela, ruchliwość, dociekliwość, podejmowanie inicjatyw, ciekawość poznawcza, zdolność przeciwstawiania się obowiązującym standardom szkolnym. W wielu sytuacjach życia szkolnego taki uczeń pełni funkcję przywódcy, jest inicjatorem różnych przedsięwzięć, ma dużo pomysłów, potrafi wciągać innych w wir swoich poczynań, cieszy się uznaniem i autorytetem wśród rówieśników. Taki sposób funkcjonowania jest najbardziej korzystny dla rozwoju ucznia. Jednocześnie generuje określone zadania dla nauczycieli.

W zupełnie odmiennej sytuacji rozwojowej znajduje się uczeń, który w procesie adaptacji do roli ucznia czwartej klasy pozostaje na boku życia szkolnego, jest bierny i nie przejawia inicjatywy w żadnej sferze funkcjonowania szkolnego. Jest jedynie obserwatorem toczącego się wokół niego życia i zachowuje znaczny dystans. Uczeń taki cechuje się niepewnością, doświadcza chwilowego braku poczucia bezpieczeństwa i w związku z tym potrzebuje zwykle dłuższego czasu na wejście w nurt codzienności edukacji przedmiotowej. Czasowo ulega także presji otoczenia i poddaje się zewnętrznym naciskom zarówno ze strony rówieśników, jak i dorosłych. Podporządkowuje swoją linię działania linii działania nauczyciela. $\mathrm{W}$ procesie adaptacji dominują u niego mechanizmy biernego przystosowania. Stopniowo jednak orientuje się i przekonuje do stylu funkcjonowania poszczególnych nauczycieli, do często nowego sposobu bycia rówieśników, strategii stawianych mu wymagań oraz coraz lepiej rozumie istotę i sens oczekiwań wobec niego. Zwykle po czasie wstępnej orientacji, ogarnięciu i zrozumieniu nowej rzeczywistości szkolnej podejmuje obowiązki wynikające $\mathrm{z}$ roli czwartoklasisty. W procesie dostrajania się do wymagań płynących z nowej roli ucznia musi otrzymać odpowiednie wsparcie, zwłaszcza ze strony nauczycieli, gdyż proces ten nie zawsze samoistnie osiąga fazę nowego zorientowania i twórczego przekraczania.

Najmniej korzystna dla rozwoju czwartoklasisty jest sytuacja, gdy w procesie adaptacji do nowej roli jego funkcjonowanie przesycone jest silnymi przeżyciami lękowymi, nad którymi nie jest on w stanie zapanować. Tak niekorzystny dla dziecka stan psychiczny powoduje całkowite zahamowanie jego autonomii i prowadzi do bezwolnego ulegania naciskom zewnętrznym, a głównie presji nauczycieli i rówieśników. Dziecko podporządkowuje się wszelkim normom życia klasowego, jest pasywne, reaktywne i zupełnie zatraca swoją indywidualność. Ze wszystkich sił stara się dostroić własną linię działania do linii działania nauczycieli, lecz zwykle to nie przynosi mu nawet złagodzenia silnych napięć i stresów, a już na pewno nie daje korzyści rozwojowych. Zachowanie dziecka podporządkowanego stwarza pozory dobrego przystosowania i w związku z tym często takiego ucznia określa się jako grzecznego, posłusznego, niesprawiającego żadnych kłopotów wychowawczych. Zwykle jednak dziecko takie charakteryzuje dualizm ról pełnionych w szkole i domu. Rzeczywistość szkolna jest dla takiego ucznia źródłem 
niekorzystnych stanów psychicznych, które z czasem mogą przekształcić się w fobię szkolną (Michalak, Misiorna 2006).

Wobec tego nauczyciele edukacji przedmiotowej mają do spełnienia ważne zadania, specyfikę których określa rodzaj strategii wchodzenia w rolę czwartoklasisty uruchamianych przez uczniów w różnych sytuacjach życia szkolnego. W strategii konstruowania roli najbardziej korzystnej dla rozwoju ucznia wysiłki nauczycieli powinny koncentrować się na ukierunkowywaniu jego aktywności tak, by zarówno służyła ona jego indywidualnemu rozwojowi, jak i stanowiła korzyść dla funkcjonowania całego zespołu klasowego. Dzieje się tak tylko wówczas, gdy nauczyciele powierzają uczniom zadania wymagające dużej odpowiedzialności, samodzielności i zróżnicowanej aktywności. Powinny to być zadania atrakcyjne pod względem treści i formy, problemowe, wymagające twórczego wysiłku i pozyskiwania informacji z wielu źródeł oraz zadania wymagające współpracy, polegające na niesieniu pomocy kolegom i nauczycielowi oraz wynikające z pełnienia dodatkowych funkcji. Wobec tego nauczyciele powinni zachęcać dziecko do podejmowania zadań wyzwalających jego aktywność i gwarantujących mu realizację nagromadzonego potencjału. Ważne jest zatem, by nauczyciele doceniali aktywny, dociekliwy sposób funkcjonowania ucznia i uznawali go za ogromny atut, a nie niszczyli go nadmierną kontrolą, by w końcu go stłumić. Jest to szczególnie ważne, gdyż uczniowie najczęściej nie posiadają w tym zakresie pozytywnych doświadczeń i z reguły już na etapie edukacji przedmiotowej cechują się niską motywacją poznawczą, brakiem dociekliwości badawczej, a niestety wysoką reaktywnością i unikaniem wysiłku. Raz stłamszonego zapału ucznia z reguły nie daje się ożywić.

W strategii budowania roli, w której uczeń przejawia bierność i jest w zasadzie obecny jedynie ciałem na arenie klasy, działania nauczycieli powinny polegać na przywracaniu jego zaburzonego poczucia bezpieczeństwa. Oswajanie ucznia z nowymi wyzwaniami będzie tym efektywniejsze, im nauczyciele będą bardziej wrażliwi na jego potrzeby. Konieczne jest zatem, by w delikatny i sensytywny sposób stopniowo włączali ucznia w nurt życia klasy i wspólne działania, nie stosując przy tym żadnych nacisków, a tym bardziej kar. Ważne jest, by początkowo tylko zachęcali ucznia do podejmowania zadań z własnej inicjatywy, zrealizowanie których wymaga od niego wchodzenia w interakcje rówieśnicze, oraz zadań gwarantujących szybki sukces, budzących uznanie rówieśników i podziw nauczyciela, opartych na mocnych stronach jego osobowości. Tylko takie funkcjonowanie nauczycieli, które pozwala uczniowi uwierzyć w swoje autentyczne możliwości, pozwala jakby na nowo odszukać własne miejsce w klasie, a przede wszystkim pozwala odnaleźć siebie i kroczyć drogą autonomicznego rozwoju, zapewnia bezpieczne wejście w rolę ucznia edukacji przedmiotowej i konstruktywną adaptację do jej wymagań. 
Najtrudniejsze zapewne zadanie mają nauczyciele, którzy muszą zmierzyć się z trudnościami wynikającymi z roli budowanej na poczuciu silnego, paraliżującego lęku. Proces ten komplikuje fakt, że zwykle ta najtrudniejsza dla ucznia sytuacja nie jest postrzegana zgodnie z jej treścią. Uczniowie tacy zazwyczaj są niedostrzegani przez nauczycieli, a często wręcz uznawani za grzecznych, posłusznych, zdyscyplinowanych, a więc niesprawiających żadnych problemów. Nauczyciel, który dużą wagę przywiązuje do dyscypliny, jest autokratyczny i dyrektywny, takie funkcjonowanie ucznia uznaje za olbrzymi atut. W związku z tym nie pomaga mu uruchomić strategii aktywnego konstruowania roli czwartoklasisty. Najczęściej jest to efekt ignorancji nauczyciela oraz niezrozumienia prawidłowości i mechanizmów rozwoju dziecka. Uczeń w takiej sytuacji jest jakby zawieszony w próżni edukacyjnej, która nie stymuluje jego rozwoju i nie dostarcza wiedzy o tym, jaki jest, gdzie jest oraz dokąd zmierza. Szansą rozwojową dla takiego dziecka jest spotkanie na edukacyjnej drodze nauczyciela refleksyjnego, czujnego i wrażliwego obserwatora, dostrzegającego w uczniu to, co niezauważalne na pierwszy rzut oka, a często ukryte pod maską reaktywnych i życzeniowych zachowań. Trafnie tę nauczycielską rolę opisuje Erik Erikson (2004), mówiąc, że nauczyciel musi być człowiekiem, który wie, jak zauważać, respektować i akceptować to, czego dziecko umie dokonać samo. Sytuacja ucznia zalęknionego jest tym trudniejsza, im dłużej ten stan trwa. Jeśli uczeń do tej pory funkcjonował w roli ucznia, płacąc tak silnie niekorzystnymi napięciami psychicznymi, to wytrącenie go z tego stanu wymaga zintegrowanych i długoterminowych oddziaływań. Pomoc taka powinna być szeroko zakrojona i włączająca specjalistów: psychologa dziecięcego i neurologa. Silne napięcia trwające przez dłuższy czas stanowią bardzo poważny bodziec uszkadzający delikatną naturę psychiczną dziecka.

Dobre zatem pełnienie przez nauczyciela funkcji wspierającej uczniów w procesie budowania tożsamości czwartoklasisty wymaga ogromnej wrażliwości na dziecko i jego funkcjonowanie, a także wielu specjalistycznych kompetencji, wśród których diagnozowanie, monitorowanie i ewaluacja wydają się szczególnie istotne.

\section{ZADANIA NAUCZYCIELI EFEKTYWNIE WSPIERAJĄCYCH UCZNIÓW W PROCESIE KONSTRUOWANIA ROLI CZWARTOKLASISTY}

Wsparcia udzielanego uczniom przez nauczycieli w procesie konstruowania roli czwartoklasisty, zwłaszcza na starcie edukacji przedmiotowej, nie da się przecenić. Dziecko będzie miało możliwość korzystania ze wszystkich szans rozwojowych, jakie stwarza mu szkoła (i to nie tylko na etapie edukacji przedmiotowej), tylko wtedy, gdy odpowiednio zostanie zorganizowane wychowanie i nauczanie, któ- 
re sprzyjać będzie konstruktywnemu i podmiotowemu funkcjonowaniu. Fundamentem tego procesu powinna być autentyczna indywidualizacja procesu kształcenia, gdyż każde dziecko niezależnie od uniwersaliów rozwija się w sobie tylko właściwy sposób i posiada bagaż indywidualnych doświadczeń. Ważne jest przy tym, by nauczyciel konstruował proces kształcenia bazujący na mocnych stronach dziecka, co wzmocni poczucie jego zadowolenia i kompetencji tak istotne zwłaszcza w początkowej fazie adaptacji do roli. Ponadto konieczne jest, by organizując warunki dla rozwoju ucznia, brał pod uwagę zarówno jego dotychczasowe i aktualne możliwości, które determinują funkcjonowanie czwartoklasisty tu i teraz, jak i te, od których zależeć będzie możliwość osiągnięcia wyższych etapów w jego rozwoju. Każda nowa forma zachowania dziecka wynika z jego uprzednich doświadczeń i jest zarazem rezultatem jego aktywnej interakcji z otoczeniem, a także oddziaływań edukacyjnych pełniących funkcję stymulatorów. Ciągłość edukacyjna i zarazem bezkolizyjne przejście będzie możliwe tylko wówczas, gdy nauczyciel respektować będzie jedną z zasad integracji procesu kształcenia mówiącą o tym, że poprzedzający etap staje się częścią składową następnego.

$\mathrm{W}$ analizie zadań nauczyciela autentycznie wspierającego ucznia $\mathrm{w}$ procesie konstruowania roli czwartoklasisty można wyróżnić pewne ich grupy:

1. Zadania w zakresie diagnozowania i monitorowania bieżącego funkcjonowania adaptacyjnego uczniów:

- prowadzenie wrażliwej i systematycznej obserwacji zmian zachodzących w uczniu, grupie oraz klasie w różnych sytuacjach życia szkolnego oraz w różnych fazach procesu kształcenia;

- zwracanie uwagi na zachowanie uczniów w kontekście przyczyn, specyfiki rozwojowej i szerokim spektrum uwarunkowań sytuacyjnych;

- rejestrowanie danych za pomocą odpowiednio dobranych metod i narzędzi;

- odbieranie i natychmiastowe reagowanie na płynące od uczniów sygnały;

- stymulowanie uczniów do autokontroli;

- budowanie zaufania uczniów do nauczycieli;

- nawiązanie pozytywnych relacji z dotychczasowymi nauczycielami, opiekunami i rodzicami dzieci.

2. Zadania w zakresie planowania działań wspierających uczniów w procesie adaptacji:

- opracowanie danych w kontekście konstruowania programów wspierających indywidualnego ucznia i zespołu klasowego;

- wyznaczenie celów rozwoju ucznia i zespołu klasowego w perspektywie „tu i teraz” oraz „tam i potem”; 
- skonfrontowanie osobistych wymagań i standardów zewnętrznych z możliwościami, potrzebami i zainteresowaniami uczniów;

- planowanie ciągu sytuacji sprzyjających działaniom pomocowym;

- planowanie strategii wspierania uczniów przez dobór odpowiednich metod, form i narzędzi;

- opracowanie oferty różnorodnych sposobów organizowania aktywności uczniów w celu stymulowania, podtrzymywania i ukierunkowywania ich zaangażowania oraz zwiększenia atrakcyjności i efektywności proponowanych zadań, sprzyjających osiąganiu wewnętrznych i zewnętrznych standardów;

- stymulowanie indywidualnego rozwoju każdego ucznia;

- aktywizowanie społecznego wsparcia rozwoju ucznia (organizowanie współpracy z uczniowskim środowiskiem rodzinnym i lokalnym);

- tworzenie przyjaznej dla każdego ucznia przestrzeni edukacyjnej;

- uruchamianie autorefleksji i oceny własnej praktyki w kontekście użyteczności, funkcjonalności, celowości i efektywności.

3. Zadania w zakresie komunikowania wspierającego uczniów w procesie adaptacji:

- empatyczne informowanie ucznia oraz jego rodziców o zakresie i jakości zmian w funkcjonowaniu czwartoklasisty;

- wyrażanie ocen konstruktywnych, wspierających, motywujących do dalszego doskonalenia własnej pracy i siebie;

- wzmacnianie uczniów do wysiłku przez dawanie wskazówek do dalszej pracy;

- koncentrowanie się na mocnych stronach osobowości ucznia, jego postępach i sukcesach w procesie wyrażania opinii;

- formułowanie ocen nieetykietyzujących uczniów;

- wskazywanie i wyjaśnianie braków oraz popełnionych błędów w celu nakreślenia możliwych dróg ich zmian;

- przekazywanie informacji oceniających w warunkach intymnych, bezpiecznych, a także wyrażających szacunek wobec odbiorcy (Michalak 2013).

Rozważania dotyczące funkcji nauczyciela w procesie wspierania czwartoklasistów zmagających się z wyzwaniami nowej roli należy uzupełnić o spostrzeżenia dotyczące zadań, jakie ma do spełnienia nauczyciel edukacji początkowej. Nauczyciel dziecka na wcześniejszym etapie kształcenia jest nie tylko obiektem uwielbienia, ale

niesie na swych barkach ogromną odpowiedzialność, w jego rękach bowiem leży dalszy rozwój dziecka. Korzystając z silnego emocjonalnego nastawienia swoich 
uczniów, kształtuje ich umysły, wyposażając je w podstawowe narzędzia zdobywania wiedzy: znajomość pisma, rachunku matematycznego, zasad logiki i tym podobne. Kształtuje również samoocenę dzieci, nagradzając lub bagatelizując rezultaty ich pracy. Sukcesy lub porażki w pierwszych klasach szkoły podstawowej nierzadko decydują o przebiegu całej kariery szkolnej, a także pracy zawodowej dorosłego już człowieka (Appelt 2005, s. 280).

Najbardziej zatem elementarne zadania nauczyciela edukacji początkowej wynikają z jego odpowiedzialności za jakość rozwoju dziecka, a więc opanowanie kompetencji poznawczych, społecznych, emocjonalnych i motorycznych na takim poziomie, który czyni je gotowym do wejścia w strefę najbliższego rozwoju wyznaczoną przez wymagania edukacji przedmiotowej. Chodzi zatem o to, by metodyka edukacji zintegrowanej była efektywna, czyli oparta na najnowszych koncepcjach wyrosłych z badań warunków skuteczności oddziaływań dydaktyczno-wychowawczych podejmowanych wobec dziecka. Koncepcje te podkreślają aktywną rolę ucznia w procesie konstruowania wiedzy, konieczność organizowania zadań problemowych, twórczych wymagających myślenia w alternatywach, kooperatywnego działania, respektujących indywidualne style uczenia się oraz założenia teorii wielorakiej inteligencji. W centrum procesu kształcenia stawiają dziecko i jego rozwój, a roli nauczyciela upatrują w organizacji zróżnicowanych co do treści i formy sytuacji edukacyjnych wywołujących określone przeżycia poznawcze i emocjonalne. Jednocześnie respektują kluczowy dla wszechstronnego rozwoju każdego dziecka paradygmat indywidualizacji, który głównie wyraża się w pluralizacji strategii, metod, form, celów i treści nauczania.

Głównymi zadaniami nauczyciela wrażliwego na dziecko i jego edukacyjną przyszłość są zatem:

- diagnozowanie strefy aktualnego i najbliższego rozwoju;

- wzbudzanie i podtrzymywanie osobistego zaangażowania ucznia w proces konstruowania struktur wiedzy, który wiedzie go do rozwoju poczucia kompetencji i zaufania do siebie i innych;

- prezentowanie kluczowych form informacji na wiele sposobów, wyważając przy tym proporcje między samodzielnymi dociekaniami, poszukiwaniami wiedzy przez ucznia a przekazem gotowych znaczeń;

- bycie kompetentnym źródłem wiedzy, ale i wiedzy „o wiedzy”, by uczeń zdobył narzędzia poznawania świata i siebie samego;

- stawianie i regulowanie wymagań oraz wyzwań poznawczych i społecznych;

- organizowanie środowiska uczenia się indywidualnego i zespołowego, by dziecko nabyło kompetencje samodzielnego i kolektywnego uczenia się;

- wrażliwe i konstruktywne krytykowanie; 
- życzliwa opieka i nienatarczywa pomoc;

- umożliwianie dziecku odnoszenia sukcesów, zwłaszcza kiedy zadanie jest trudne, kształtuje to poczucie sprawstwa i zaufanie do własnych możliwości oraz efektywności działań, co oswaja z trudnościami (Michalak 2013).

Ponadto nauczyciele zobowiązani są do podejmowania działań wspierających dziecko w pokonywaniu trudności, jakie mogą pojawić się wraz z podjęciem roli czwartoklasisty, przez rozumną i dobrze zaplanowaną profilaktykę. Jest to szczególnie ważne pod koniec edukacji elementarnej, kiedy dzieci są już w zasadzie gotowe opuścić ten etap kształcenia. Chodzi przede wszystkim o ukształtowanie pozytywnych nastawień i otwartości na zmiany. Te specyficzne zadania można ująć $\mathrm{w}$ formie organizowania tzw. działań pomostowych, jak:

- zapoznanie dzieci i ich rodziców z przyszłym wychowawcą i nauczycielami;

- zapoznanie uczniów z fizyczną przestrzenią szkoły, z której będą korzystali po przekroczeniu progu edukacji przedmiotowej;

- zapoznanie uczniów i rodziców z cyfrowym systemem oceniania przez wyjaśnienie zasad jego stosowania;

- wrażliwe wprowadzanie form kontrolowania postępów uczniów, charakterystycznych na drugim etapie szkoły podstawowej.

Absolwent nauczania początkowego ma już za sobą co najmniej trzyletnią historię pełnienia roli ucznia. Historia ta nie należy jedynie do przeszłości, ale tworzy niezwykle istotną bazę przyszłości dziecka, która determinuje jego karierę szkolną. Najczęściej konstruowaną w tej samej instytucji, pod opieką grona pedagogicznego, do którego należy dotychczasowy nauczyciel dziecka. Fakt ten powinien ułatwiać dziecku podjęcie nowej roli ucznia na etapie edukacji przedmiotowej i stworzyć możliwość bezpiecznego oraz efektywnego odnalezienia się w nowej sytuacji. Nowi nauczyciele oraz dotychczasowy wychowawca powinni dążyć do współpracy przez zaplanowanie obszarów wspólnych działań, które stopniowo pozwolą dziecku stawać się samodzielnym, kompetentnym i autonomicznym uczestnikiem oraz sprawcą swojego edukacyjnego rozwoju.

\section{PODSUMOWANIE}

Współczesne koncepcje psychologii rozwojowej podkreślają, iż człowiek to jednostka zależna od zewnętrznego otoczenia i aktywnie w nim działająca. Dlatego podjęcie roli czwartoklasisty uzależnione jest od szeregu czynników społecznych oraz pedagogicznych. Odpowiednia opieka, wsparcie, zwłaszcza nauczycieli i wychowawcy, a także dobre relacje z rówieśnikami, dopasowanie wymagań do możliwości i oczekiwań dziecka przekładają się znacząco na eliminowanie bądź 
minimalizacje ryzyka porażki w procesie konstruowania roli czwartoklasisty. Nie można zapomnieć o istotnej roli specjalistycznej pomocy, udzielanej dziecku z problemami adaptacyjnymi, ale także o wsparciu odpowiednim do jego potrzeb, zasobów na tyle, aby chętnie angażowało się w zmianę i uruchamiało wewnętrzną motywację do pomyślnego wejścia w nową rolę ucznia (Brzezińska 2005).

\section{LITERATURA}

Appelt K., 2005, Wiek szkolny. Jak rozpoznać potencjał dziecka?. W: A.I. Brzezińska (red.), Psychologiczne portrety człowieka. Praktyczna psychologia rozwojowa. Gdańsk, Gdańskie Wydawnictwo Psychologiczne.

Brzezińska A., 2004, Społeczna psychologia rozwoju. Warszawa, Wydawnictwo Naukowe Scholar.

Brzezińska A.I., 2005, Jak skutecznie wspomagać rozwój?. W: A.I. Brzezińska (red.), Psychologiczne portrety człowieka. Praktyczna psychologia rozwojowa. Gdańsk, Gdańskie Wydawnictwo Psychologiczne.

Erikson E.H., 2004, Tożsamość a cykl życia. Poznań, Wydawnictwo Zysk i S-ka.

Hajnicz W., Konieczna A., 2013, Diagnozowanie kompetencji dzieci w procesie edukacyjnym. Warszawa, Wydawnictwo Akademii Pedagogiki Specjalnej.

Michalak R., Misiorna E., 2006, Konteksty dojrzałości szkolnej. W: Doradca Nauczyciela Sześciolatków. Warszawa, Centrum Metodyczne Pomocy PsychologicznoPedagogicznej.

Michalak R., 2013, Dziecko u progu edukacji przedmiotowej. Studium teoretycznoempiryczne. Poznań, Wydawnictwo Naukowe UAM.

Rychlewska K., 2006, Adaptacja dzieci do sytuacji szkolnej. „Edukacja i Dialog”, nr 3, 22-26.

Wilski M., 2011, Adaptacja uczniów do warunków szkoły. W: S. Kowalik (red.), Psychologia ucznia i nauczyciela: podręcznik akademicki. Warszawa, PWN.

THE SCHOOL'S ROLE IN THE PROCESS OF CONSTRUCTING THE ROLE OF PUPIL OF SECONDARY EDUCATION

\footnotetext{
Abstract: Taking the role of the student of secondary education is connected with the necessity to learn new behaviors because existing and well mastered behaviors are ineffective. It initiates psychosocial changes. Adaptation to the role may be a form of development. However, it may cause difficulties when a student is experiencing only the external pressures
} 
and does not have appropriate resources and does not receive social support. The text shows the nature and importance of social support for students building the role on the secondary level. Additionally, it focuses on teachers' tasks.

Keywords: building the role of pupil of secondary education; strategies of adaptation; adaptive support; the tasks of teachers; secondary education 